\title{
A study to detect factors influencing the formation of loyal customers' mental image
}

\author{
Erfan Sobhaninia, Naser Azad" and Mahmoud Samiei Nasr
}

Department of Management, Islamic Azad University, South Tehran Branch, Tehran, Iran

\begin{tabular}{|c|c|}
\hline CHRON I C L E & A B S T R A C T \\
\hline $\begin{array}{l}\text { Article history: } \\
\text { Received May 12, } 2013 \\
\text { Accepted July } 15,2013 \\
\text { Available online } \\
\text { July } 202013 \\
\text { Keywords: } \\
\text { Banking industry } \\
\text { Brand loyalty } \\
\text { Mental image }\end{array}$ & $\begin{array}{l}\text { Understanding customers' behavior normally helps planning better marketing strategies, which } \\
\text { could lead to an increase in market share and profitability. Loyal customers are always } \\
\text { considered as the most important assets for any firm. This paper presents a survey to detect } \\
\text { factors influencing the formation of loyal customers' mental image. The proposed study uses } \\
\text { factor analysis to determine these factors by designing a questionnaire and distributing among } \\
\text { some loyal customers who do banking business in Bank Melli Iran located in city of Tehran, } \\
\text { Iran. The results indicate that there were eight important factors influencing customer loyalty } \\
\text { including social status, business identity, brand strength, the contract role, organizational } \\
\text { benefit, consumer rights, organizational image and supporting power. }\end{array}$ \\
\hline
\end{tabular}

\section{Introduction}

Branding plays an important role on marketing planning and building good business enterprises. Loyal customers could be considered as long term intangible assets and reduce the chance of having any financial crises. However, one primary question is on how business units are able to find important factors in shaping loyal customers and what factors help make improvement on having reliable and loyal customers (Yüksel \& Akgül, 2007; Fournier et al., 2008; Konrad, 2010; Loureiro \& Kastenholz, 2011). Auh et al. (2007) proposed a model of co-production and investigated the links between co-production and customer loyalty as well as the factors, which could increase the level of co-production in a financial services context. They also considered the relationships of customer expertise, customer-advisor communication, customer affective commitment, and interactional justice with the level of co-production. They reported that co-production plays important role as a basis for competition in the financial services industry. De Beni et al. (2007) tested the effect of age on some mental operations for independence of components and reported that image generation, maintenance and transformation could be influenced by kind of image and aging, supporting a model of their cognitive segregation, differently.

* Corresponding author.

E-mail addresses: dr.naserazad@yahoo.com (N. Azad)

C 2013 Growing Science Ltd. All rights reserved. doi: $10.5267 /$ j.ds1.2013.07.006 
Branding research has largely concentrated on consumer goods markets and in many business markets, the company's reputation has a strong impact on buying decisions, which could differ from the more specific product related effects of the brand's image. Cretu and Brodie (2007) studied these differences by testing the hypotheses about the effects of brand image and company reputation on customers' perceptions of product and service quality, customer value, and customer loyalty in a business market where there were three manufacturers marketing their brands directly to a large number of small firms. They reported that the brand's image had a more specific impact on the customers' perceptions of product and service quality while the company's reputation had a bigger impact on perceptions of customer value and customer loyalty.

Chang and Chen (2008) proposed an integrating theoretical framework for testing the relationships among customer interface quality, satisfaction, switching expenditures, and e-loyalty. In addition, this study argued that the relationships among these constructs could be moderated by Internet experience. Empirical analyses were executed based on structural equations modeling analysis. The findings confirmed that customer interface quality, including customization, interaction, convenience and character, contributes to generating e-loyalty. More specifically, the results demonstrated that convenience directly enhances e-loyalty and customer interface quality positively influenced switching expenditures for customers with higher Internet experience.

Fernández-Sabiote and Román (2012) explored how overall customer loyalty was constructed as a consequence of the value provided by each channel. They also analyzed the moderating effect of complexity of services implemented and customers' Internet access in the service value-loyalty link. The model was examined with a sample of 302 multichannel financial services customers who applied both the offline and the online channel. Their results indicated that offline perceived service value increased online perceived value; offline value had a stronger impact on overall loyalty than online value; and online service complexity and Internet adoption could moderate the effect of service value on overall loyalty.

Image building is an important technique both for customer retention. Helgesen et al. (2010) investigated chain image and store image as well as store satisfaction as mediators of assortment, service quality and price, on store loyalty. They reported that chain image and store image were various concepts and a two-level image building approach was an essential aspect for petrol retailing.

According to Hosany and Martin (2012), self-image congruence helps describe and forecast various aspects of consumer behavior. They examined a model, which includes self-image congruence, cruise ship passengers' experiences, satisfaction, and behavioral intention. Path modeling examined the hypotheses and the results indicated that self-image congruence influences passengers' experiences but indirectly affecting satisfaction levels. In addition, satisfaction was positively associated with respondents' propensity to recommend. Kressmann et al. (2007) examined a model dealing with direct and indirect impacts of self-image congruence on brand loyalty and reported some positive effects between these components. Lai et al. (2009) examined the relationships among service quality, value, image, satisfaction, and loyalty in China and reported that value had both a direct and indirect influence on customer loyalty.

Lee et al. (2010) investigated the relationships in terms of customer store loyalty by applying meansend chains (MEC) analysis to test the linkages between department stores' service attributes, involvement, satisfaction and loyalty each of which the customer regards as important. Loureiro et al. (2011) investigated corporate reputation, satisfaction, delight, and loyalty towards rural lodging units in Portugal. Nguyen and Leblanc (2001) studied corporate image and corporate reputation in customers' retention decisions in services. Sahin et al. (2011) studied the impacts of brand experiences, trust and satisfaction on building brand loyalty. Shamsuddoha and Alamgir (2004) investigated loyalty and satisfaction construct in retail banking in an empirical study on bank 
customers. Azad and Mohammadi (2013) attempted to find important factors influencing on packaging dairy products.

\section{The proposed study}

This paper presents a survey to detect factors influencing the formation of loyal customers' mental image. The proposed study uses factor analysis to determine these factors by designing a questionnaire and distributing among some loyal customers who do banking business in Bank Melli Iran located in city of Tehran, Iran. The proposed study uses factor analysis to perform the investigation. Since factor analysis is sensitive to skewness of the factors, we first look at basic statistics associated with 28 factors extracted. Table 1 demonstrates details of 28 factors along with basic statistics.

Table 1

The summary of basic descriptive statistics

\begin{tabular}{lcccccc}
\hline \multicolumn{1}{c}{ Description } & $\mathrm{N}$ & Range & \multicolumn{2}{c}{ Skewness } & \multicolumn{2}{c}{ Kurtosis } \\
& Statistic & Statistic & Statistic & Std. Error & Statistic Std. Error \\
\hline VAR00001 Rating agencies & 300 & 8.00 & -.991 & .141 & .581 & .281 \\
VAR00002 Organization identification & 300 & 8.00 & -.699 & .141 & .163 & .281 \\
VAR00003 Environment & 300 & 8.00 & -.156 & .141 & -.212 & .281 \\
VAR00004 Advertisement & 300 & 8.00 & -.829 & .141 & .007 & .281 \\
VAR00005 Physical environment & 300 & 8.00 & -.896 & .141 & .182 & .281 \\
VAR00006 Technical specification & 300 & 6.00 & -.924 & .141 & -.473 & .281 \\
VAR00007 Education & 300 & 8.00 & -.439 & .141 & -.478 & .281 \\
VAR00008 Image & 300 & 8.00 & -.223 & .141 & -.494 & .281 \\
VAR00009 Customer orientation & 300 & 8.00 & -.527 & .141 & .022 & .281 \\
VAR00010 Organizational image & 300 & 8.00 & -.889 & .141 & .160 & .281 \\
VAR00011 Society & 300 & 8.00 & -.779 & .141 & .000 & .281 \\
VAR00012 Delivery time & 300 & 8.00 & -.364 & .141 & -.560 & .281 \\
VAR00013 First impression & 300 & 8.00 & -.883 & .141 & -.243 & .281 \\
VAR00014 Age and gender & 300 & 8.00 & -.153 & .141 & -.983 & .281 \\
VAR00015 Communication & 300 & 8.00 & -.751 & .141 & .176 & .281 \\
VAR00016 Diversity in services & 300 & 8.00 & .155 & .141 & -.379 & .281 \\
VAR00017 Special orders & 300 & 8.00 & -.084 & .141 & -.813 & .281 \\
VAR00018 Quality of services & 300 & 8.00 & .073 & .141 & -.505 & .281 \\
VAR00019 Service awareness & 300 & 8.00 & -.621 & .141 & .173 & .281 \\
VAR00020 Discount purchases & 300 & 8.00 & -.118 & .141 & -.438 & .281 \\
VAR00021 After sales services & 300 & 8.00 & -.838 & .141 & .527 & .281 \\
VAR00022 Social personality & 300 & 8.00 & -.099 & .141 & -.487 & .281 \\
VAR00023 Communication & 300 & 8.00 & -.108 & .141 & -.214 & .281 \\
VAR00024 Affective commitment & 300 & 8.00 & -.293 & .141 & -.247 & .281 \\
VAR00025 Previous experience from brand & 300 & 8.00 & -.904 & .141 & .796 & .281 \\
VAR00026 Interactional justice & 300 & 8.00 & -.237 & .141 & -.163 & .281 \\
VAR00027 Online services & 300 & 8.00 & -.813 & .141 & .418 & .281 \\
VAR00028 Price & 300 & 8.00 & -.962 & .141 & 1.078 & .281 \\
\hline Valid N (listwise) & 300 & & & & & \\
\hline & & & & & & \\
\hline
\end{tabular}

As we can observe from the results of Table 1 none of the 28 factors has unusual skewness, which means we can rely on the results and no data needs to be removed. In addition, determinants of the components are greater than zero, which means we can rely on factor analysis. Fig. 1 shows scree plot of the factors. As we can observe from the figure, the curve becomes flat after $8^{\text {th }}$ factors and we can, therefore conclude that there are 8 influencing factors. These factors are including social status, 
business identity, brand strength, the contract role, organizational benefit, consumer rights, organizational image and supporting power.

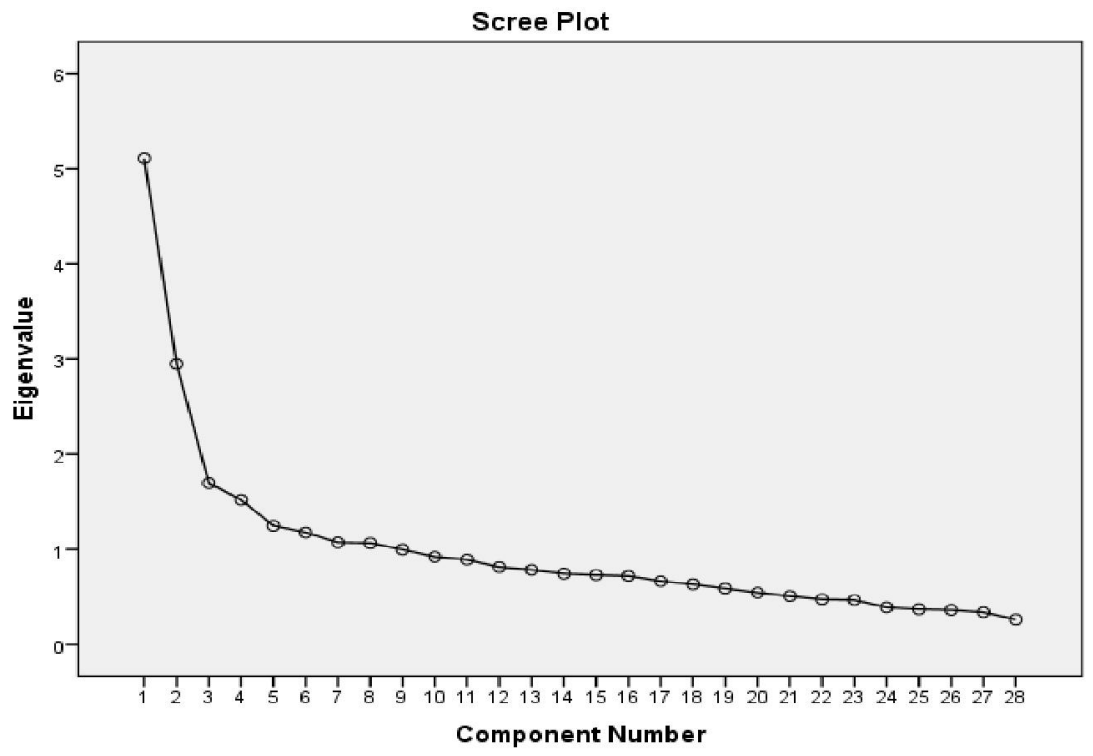

Fig. 1. Scree plot for 28 factors

Next, we present each component of in details.

\section{The results}

In this section, we present details of all 8 factors associated with the proposed study.

\subsection{The first factor: Social relationship}

The first factor, social relationship, consists of seven factors including being customer oriented, having a good image, environment, society, age and gender, education and social characteristics. Table 2 demonstrates the summary of our findings.

\section{Table 2}

The summary of factors associated with the social relationship

\begin{tabular}{lcccc}
\hline Option & Factor weight & Eigen value & \%of variance & Accumulated \\
\hline Being customer oriented & .738 & & & \\
Having a good image & .732 & & & \\
Environment & .650 & & & \\
Society & .580 & & & \\
Age and gender & .537 & & & \\
Education & .510 & & & \\
Social characteristics & .472 & & & \\
\hline Cronbach alpha $=0.793$ & & & &
\end{tabular}

According to the results of Table 2, being customer oriented is the most important factor followed by having a good image and environment.

\subsection{The second factor: Contracts}

The second factor is associated with different methods used for doing business, which includes online business, interactional justice and affective commitment and the results are summarized in Table 3. 
Table 3

The summary of the second factor

\begin{tabular}{lcccc}
\hline Option & Factor weight & Eigen value & \%of variance & Accumulated \\
\hline Online business & .718 & & & \\
Interactional justice & .683 & 2.946 & 10.523 & 28.766 \\
Affective commitment & .566 & & & \\
\hline Cronbach alpha $=0.842$ & & & &
\end{tabular}

The results of Table 3 indicate that online business is the most important factor followed by international justice and affective commitment.

\subsection{The third factor: Customer's right}

Customer's right is the third factor extracted in our survey, which includes quality of services, diversity and special orders and the weights of these components are summarized in Table 4 as follows,

Table 4

The summary of factors associated with customers' right

\begin{tabular}{lcccc}
\hline Option & Factor weight & Eigen value & \%of variance & Accumulated \\
\hline Quality of services & .743 & & & \\
Diversity & .699 & 1.694 & 6.050 & 34.817 \\
\hline Special order & .644 & & & \\
\hline Cronbach alpha $=0.719$ & & &
\end{tabular}

Cronbach alpha $=0.719$

The results of Table 4 indicate that quality of services is the most important factor followed by diversity and special order.

\subsection{The fourth factor: Business identification}

Business identification is the fourth factor in our exploration study, which consists of four factors including organizational image, technological characteristics, relationships and price. Table 5 demonstrates the results of our survey.

Table 5

The summary of business identification

\begin{tabular}{lcccc}
\hline Option & Factor weight & Eigen value & \%of variance & Accumulated \\
\hline Organizational image & .596 & & & \\
Technological characteristics & .581 & 1.518 & 5.422 & 40.239 \\
Relationships & .558 & & & \\
Price & .456 & & & \\
\hline Cronbach alpha $=0.719$ & & & &
\end{tabular}

The results of Table 5 demonstrate that organizational image is the most influential factor followed by technological characteristics, relationship and price is the last component in terms of priority.

\subsection{The fifth factor: Organizational advantage}

This factor includes three components including delivery time, awareness and the first impression. Table 6 shows details of our findings, 
Table 5

The summary of factors associated with advantages

\begin{tabular}{lcccc}
\hline Option & Factor weight & Eigen value & \%of variance & Accumulated \\
\hline Delivery time & .640 & & & \\
Awareness & .618 & 1.246 & 4.451 & 44.690 \\
\hline First impression & .545 & & & \\
\hline Cronbach alpha $=0.707$ & & & &
\end{tabular}

The results of the fifth factor indicate that delivery time and being on time is the most important factor followed by awareness and first impression.

\subsection{The sixth factor: Image}

Image is the next factor in our investigation and it involves with three factors including physical environment, advertisement and communication. Table 7 shows details of our findings,

Table 7

The summary of factors associated with image

\begin{tabular}{lcccc}
\hline Option & Factor weight & Eigen value & \%of variance & Accumulated \\
\hline Physical environment & .720 & & & \\
Advertisement & .646 & 1.175 & 4.195 & 48.885 \\
Communication & .504 & & & \\
\hline Cronbach alpha $=0.792$ & & &
\end{tabular}

The results indicate that physical environment is the most influential factor followed by advertisement and communication.

\subsection{The seventh factor: Supportive power}

Supportive power is the next factor influencing brand loyalty and it includes two components including after sales services and promotions. Table 8 demonstrates the summary of our findings,

\section{Table 8}

The summary of factors associated with supportive power

\begin{tabular}{lrrrr}
\hline Option & Factor weight & Eigen value & \%of variance & Accumulated \\
\hline After sales services & .775 & 1.071 & 3.824 & 52.709 \\
Promotions and discounts & .696 & & & \\
\hline
\end{tabular}

The results indicate that after sales services is the most important factor and promotions and discount programs are in lower priority.

\subsection{The eighth factor: Brand power}

The last factor includes three components of organizational identity, credibility and past experiences from brand. Table 9 summarizes the results of our survey.

\section{Table 9}

The summary of factors associated with brand power

\begin{tabular}{lcccc}
\hline Option & Factor weight & Eigen value & \%of variance & Accumulated \\
\hline Organizational identity & .764 & & & \\
Organizational credibility & .682 & 1.063 & 3.797 & 56.506 \\
Past experiences from brand & .382 & & & \\
\hline
\end{tabular}

The results of Table 9 show that organizational identity is the most important factor followed by organizational credibility and past experiences from brand. 


\section{Conclusion}

In this paper, we have presented an empirical investigation to find out more about the important factors influencing the formation of loyal customers' mental image. The proposed study has implemented factor analysis to determine these factors by designing a questionnaire and distributing among some loyal customers who do banking business in Bank Melli Iran located in city of Tehran, Iran. The results have indicated that there were eight important factors influencing customer loyalty including social status, business identity, brand strength, the contract role, organizational benefit, consumer rights, organizational image and supporting power.

\section{Acknowledgment}

The authors would like to thank the anonymous referees for constructive comments on earlier version of this paper.

\section{References}

Auh, S., Bell, S. J., McLeod, C. S., \& Shih, E. (2007). Co-production and customer loyalty in financial services. Journal of Retailing, 83(3), 359-370.

Azad, N \& Mohammadi, M. (2013). An empirical survey on factors influencing on packaging dairy products. Management Science Letters, 3(7), 1901-1906.

De Beni, R., Pazzaglia, F., \& Gardini, S. (2007). The generation and maintenance of visual mental images: evidence from image type and aging. Brain and Cognition, 63(3), 271-278.

Cretu, A. E., \& Brodie, R. J. (2007). The influence of brand image and company reputation where manufacturers market to small firms: A customer value perspective. Industrial Marketing Management, 36(2), 230-240.

Chang, H. H., \& Chen, S. W. (2008). The impact of customer interface quality, satisfaction and switching costs on e-loyalty: Internet experience as a moderator. Computers in Human Behavior, 24(6), 2927-2944.

Fernández-Sabiote, E., \& Román, S. (2012). Adding clicks to bricks: A study of the consequences on customer loyalty in a service context. Electronic Commerce Research and Applications, 11(1), 3648.

Fournier, J. F., Deremaux, S., \& Bernier, M. (2008). Content, characteristics and function of mental images. Psychology of Sport and Exercise, 9(6), 734-748.

Helgesen, Ø., Ivar Håvold, J., \& Nesset, E. (2010). Impacts of store and chain images on the "quality-satisfaction-loyalty process" in petrol retailing. Journal of Retailing and Consumer Services, 17(2), 109-118.

Hosany, S., \& Martin, D. (2012). Self-image congruence in consumer behavior. Journal of Business Research, 65(5), 685-691.

Konrad, K. A. (2010). Merger profitability in industries with brand portfolios and loyal customers (No. SP II 2010-08). Discussion papers//Wissenschaftszentrum Berlin für Sozialforschung, Schwerpunkt Märkte und Politik: Forschungsprofessur \& Projekt The Future of Fiscal Federalism.

Kressmann, F., Sirgy, M. J., Herrmann, A., Huber, F., Huber, S., \& Lee, D. J. (2006). Direct and indirect effects of self-image congruence on brand loyalty. Journal of Business Research, 59(9), 955-964.

Lai, F., Griffin, M., \& Babin, B. J. (2009). How quality, value, image, and satisfaction create loyalty at a Chinese telecom. Journal of Business Research, 62(10), 980-986.

Lee, W. I., Chang, C. Y., \& Liu, Y. L. (2010). Exploring customers' store loyalty using the meansend chain approach. Journal of Retailing and Consumer Services, 17(5), 395-405.

Loureiro, S. M. C., \& Kastenholz, E. (2011). Corporate reputation, satisfaction, delight, and loyalty towards rural lodging units in Portugal. International Journal of Hospitality Management, 30(3), 575-583. 
Nguyen, N., \& Leblanc, G. (2001). Corporate image and corporate reputation in customers' retention decisions in services. Journal of retailing and Consumer Services, 8(4), 227-236.

Sahin, A., Zehir, C., \& Kitapçı, H. (2011). The effects of brand experiences, trust and satisfaction on building brand loyalty; an empirical research on global brands. Procedia-Social and Behavioral Sciences, 24, 1288-1301.

Shamsuddoha, M., \& Alamgir, M. (2004). Loyalty and satisfaction construct in retail banking-An empirical study on bank customers. The Chittagong University Journal of Business Administration, Available at SSRN.

Yüksel, A., \& Akgül, O. (2007). Postcards as affective image makers: An idle agent in destination marketing. Tourism Management, 28(3), 714-725. 